\title{
Assessment of landslide hazard from tree-ring eccentricity and from compression wood - a comparison
}

\author{
Katarzyna ŁUSZCZYŃSKA ${ }^{1, *}$, Ireneusz MALIK ${ }^{1}$, Małgorzata WISTUBA ${ }^{1}$ and Marek KRĄIEC ${ }^{2}$ \\ 1 University of Silesia in Katowice, Faculty of Earth Sciences, Będzińska 60, 41-200 Sosnowiec, Poland \\ 2 AGH - University of Science and Technology, Faculty of Geology, Geophysics and Environmental Protection, \\ al. Mickiewicza 30, 30-059 Kraków, Poland
}

Łuszczyńska, K., Malik, I., Wistuba, M., Krąiec, M., 2019. Assessment of landslide hazard from tree-ring eccentricity and from compression wood - a comparison. Geological Quarterly, 63 (2): 296-301, doi: 10.7306/gq.1472

Associate Editor - Wojciech Granoszewski

We have compared maps of landslide activity and hazard, developed with the use of two different dendrochronological indicators: tree-ring eccentricity and reaction (compression) wood. The maps were prepared based on 125 Norway spruce (Picea abies L. Karst.) trees growing at 44 sampling points, distributed over an area of $3.75 \mathrm{~km}^{2}$. In general, the two maps show similar patterns of landslide activity. However, tree-ring eccentricity yielded a greater number of dated events (246) compared to compression wood (129). Besides the differences in the absolute values of dating results, the general landslide activity and hazard zonation based on both disturbances are similar. Both growth disturbances develop as a result of stem tilting. Eccentricity develops after slight tilting, while compression wood is developed when tilting is more significant. Because of the differences in the strength of disturbing factors, which cause the development of compression wood and growth eccentricity, the best approach would be to combine the results of dating obtained from the two methods. The dendrochronological analysis of tree growth disturbances (eccentric growth and compression wood) is a promising approach for determining landslide hazards in forested mountain areas and can be applied in spatial management.

Key words: eccentric growth, reaction wood, landslide activity, Western Carpathians.

\section{INTRODUCTION}

According to the report of the World Bank, the area of land exposed to landslides on Earth reaches 3.7 million $\mathrm{km}^{2}$, with a population of 300 million people, which makes $5 \%$ of the world population (Kjekstad and Highland, 2009). The increase in the world population and the settlement of areas endangered by landslides makes it necessary to develop methods of landslide hazard assessment (Petley, 2010). An increase in the number of natural disasters (including landslides) has also been noted in the recent decades under the influence of climate changes, especially in the developing countries (Alcántara-Ayala, 2002). Landslides cause high economic losses; e.g. in Japan, Italy and India, they have been estimated at 1 billion USD per year (Schuster and Fleming, 1986). Huge costs may result even from a single landslide activity event; e.g. destructive landslides triggered in the northwestern USA by an Mw 6.8 earthquake (28.02.2001) caused economic losses of $\sim 2$ billion USD (Highland, 2003). Losses caused by the landslides can be modelled

\footnotetext{
* Corresponding author, e-mail: katarzyna_luszczynska@o2.pl Received: January 7, 2019; accepted: February 28, 2019; first published online: June 7, 2019
}

and extrapolated at diverse spatial and temporal scales. In Lower Saxony (Germany), the annual average cost of damages caused by landslides to highways has been extrapolated to 4.02 million USD (in an analysis for 1980-2010) (Klose et al., 2014).

There are numerous modern techniques providing data on landslide activity for the purpose of landslide hazard assessment and mapping (van Westen et al., 2008). The most common are field mapping and measurements or laboratory analyses, with remote sensing playing a secondary role (Metternicht et al., 2005). Airborne LIDAR provides very good data for landslide identification (Glenn et al., 2006). However, after landslide identification, another problem appears with assessing the landslide activity (Lang et al., 1999). Some landslides are relict, some are active, and it is not easy to distinguish between them (Migoń et al., 2014). There are numerous studies focusing on the assessment of landslide susceptibility and hazard. However, analyses of landslide activity are still rare (van Westen et al., 2008). The main reason is a lack of long data series on landslide activity. Modern methods, e.g. terrestrial laser scanning, can provide only short datasets, as they are all very recent (Prokop and Panholzer, 2009; García-Davalillo et al., 2014). On the other hand, dendrochronology gives a unique opportunity to obtain a long series of data on landslide activity (Lopez-Saez et al., 2012). Such coverage of long periods and the widespread presence of trees 
provide a good opportunity for landslide mapping. Trees growing on active landslides are tilted by ground movements, even if landsliding is very slow and invisible for direct observations (Malik et al., 2016). After tilting, a tree starts to develop reaction wood and eccentric rings. Both growth disturbances record landslide activity in tree rings (Shroder, 1980; Malik and Wistuba, 2012). Eccentricity occurs when wider rings are being developed on one side of the tree stem compared to narrower rings developed at the same time on the opposite side of the stem (Schweingruber, 1996). Among coniferous trees, wider rings are formed on the lower side of tilted stems. Reaction wood, i.e. compression wood in coniferous trees, is macroscopically visible as a characteristic brown/dark colour and under a microscope it can be identified by its short, thick-walled dense cells, an effect of high content of lignin and 1,4- $\beta$-galactan and proportionately lower amounts of cellulose, mannan and xylan (Shroder, 1980; Timell, 1986). Compression wood is developed on the lower side of the tilted stems of conifers.

Results obtained from analyses of reaction wood and eccentric rings of trees spread over an entire slope can be used to map the landslide hazard. There are some studies where growth disturbances are analysed together and do not occur simultaneously, both in one tree-ring series and in data sets developed from several trees (Wistuba et al., 2018). This suggests that maps developed from reaction wood and eccentricity analysed in the same samples may show different levels of landslide activity. The aim of our study was to compare landslide hazard maps yielded separately from eccentric growth and compression wood.

\section{STUDY AREA}

The study area covers $3.75 \mathrm{~km}^{2}$ located in the massif of Sucha Mountain (1040 m a.s.I.) in the Beskid Żywiecki Mts., Western Carpathians, southern Poland, central Europe (Fig. 1). The bedrock is composed of the Carpathian flysch deposits: sandstones and shales (Stupnicka, 2013). Landslides of various types (e.g., flow-type, extensive rotational, shallow, etc.) occur in the study area and the terrain is dissected by V-shaped river valleys. Slope inclinations of headwater areas and the lower parts of the $\mathrm{V}$-shaped valleys are $25-45^{\circ}$. Landslides occur on moderately steep slopes $\left(5-15^{\circ}\right)$ with headscarps and secondary scarps serving as exceptions $\left(>25^{\circ}\right)$. According to Hess (1965), the study area is situated in the cold climatic zone with an annual precipitation total of $1136 \mathrm{~mm}$ at the closest gauging station (Żabnica, $550 \mathrm{~m}$ a.s.l., $5 \mathrm{~km} \mathrm{~S}$ from the study area). The investigated area belongs to the lower montane forest belt. Although natural plant communities are deciduous and mixed forests of common beech (Fagus sylvatica L.) and silver fir (Abies alba Mill.) (Seneta and Dolatowski, 2008) there, the area is now covered by monoculture forests of Norway spruce (Picea abies L. Karst.).

\section{METHODS}

To date landslide activity from eccentric growth and compression wood, we used standard increment borers and collected cores from Picea abies trees. Samples were taken at 44 sampling points, with locations determined from orthoimages (showing the extent of coniferous forests; Fig. 1) and from a digital elevation model (DEM) based on airborne LiDAR ones with respect to relief features. At least one sampling point has been located on each landslide in the study area and at least one on each slope devoid of landslide landforms.

The aim of our study was to obtain data on the local activity of landsliding at each sampling point. Due to high spatial variability of landsliding and the need of obtaining adequate data representative for small surfaces of sampling points we have cored a limited number of trees located as close as possible to selected sampling point and one to another (with a maximum distance between cored trees not exceeding a few tens of metres). In addition, we were allowed to sample only up to 150 trees over the entire mountain massif under analysis (permission provided by the Polish State Forests). Therefore, the assumption was to sample three Norway spruce specimens per sampling point. However, trees with stem injuries and defolia-

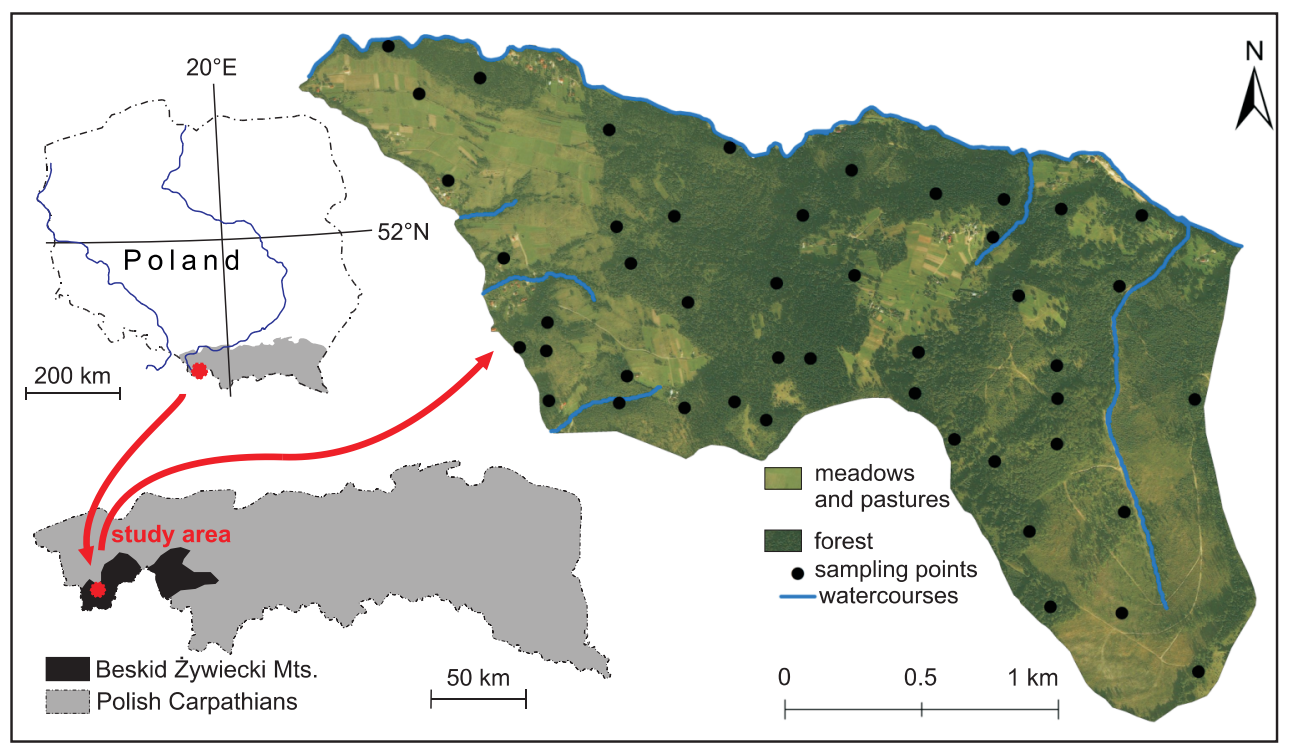

Fig. 1. Location of the study area and the distribution of sampling points 
tion were excluded from the study, as were trees with a stem circumference less than $50 \mathrm{~cm}$ at the breast height. Therefore, at some sampling points it was possible to sample only two trees.

Samples were collected from a total of 125 trees. Two cores were taken from each tree: one from the upslope and the other from the downslope side of the stem. The collected cores were glued on wooden holders and, after drying, gradually sanded to reveal the structure of the wood and ring boundaries. Sanding has been done with the use of manual grinders and sanding papers with a grain size of $100,250,500$ and 1000 .

To identify tree-ring eccentricity, we measured tree-ring widths in all sampled cores. Measurements were performed using a RINNTECH LinTab measuring system and TSAPWin software. The tree-ring curves measured on the opposite sides of each stem were compared in pairs (up- and downslope curves from each tree) and visually cross-dated to identify wedging, false or missing rings. Next, the occurrence of eccentric tree rings has been dated with the use of an algorithm by Wistuba et al. (2013). Landslide events were dated from tree-ring eccentricity with the use of local reference thresholds (Malik and Wistuba, 2012). The thresholds represent an average level of the yearly variation of the eccentricity index, calculated from 10 trees growing on an adjacent slope devoid of any landslide relief (Wistuba et al., 2013). In the case of the study area, the upslope reference threshold is $32.79 \%$ and the downslope reference threshold is $-38.81 \%$.

Dating of compression wood has been performed visually under the binocular microscope. The occurrence of compression wood was determined best with the criterion of the dark brown colour of the whole ring or its part resulting from thicker cell walls and smaller cell lumens (Yumoto et al., 1983). In case of any doubts regarding the presence of compression wood, we prepared microsections of wood with the use of core microtome, and analysed wood structure with a transmitted light microscope (Gätner and Nievergelt, 2010). In each sampled core, we dated the onset sequences of compression wood in rings.

We compared the results of dating obtained for 2-3 trees sampled at each sampling point. We assumed that an event of landsliding occurred if growth disturbances were dated in one calendar year in at least 2 trees growing at one sampling point.
Dating has been performed separately for tree-ring eccentricity and compression wood.

The results of dendrochronological dating based on the two growth disturbances were used to determine the average frequency of landslide events at each sampling point. We calculated the average number of tree-ring eccentricity events and compression wood events per 10 years. Using a GIS-based approach, values of the average frequency of landslide events (results from tree-ring eccentricity and compression wood, separately) were interpolated into two landslide activity maps: one based on eccentricity and the other based on reaction wood. The maps were developed using the spline interpolation method (ArcGIS Help, 2017).

\section{RESULTS}

In the trees sampled in the study area, we identified a total of 375 growth disturbances, including both eccentric growth and compression wood. The oldest eccentricity event in the trees under study dates back to 1919 . The oldest event of compression wood dates back to 1922 (Fig. 2). We identified 246 (65.6\%) events of tree-ring eccentricity and 129 (34.4\%) events of compression wood (Fig. 2). Despite this general disproportion, the temporal patterns of landslide activity obtained for the whole study area (from eccentricity and from compression wood, separately) were similar (Fig. 2). Both growth disturbances yielded the highest landslide activity in the same years: 1995, 2002 and 2014 (Fig. 2).

Furthermore, the developed maps present similar spatial patterns of interpolated landslide activity, regardless of the type of growth disturbance used for the map construction (Fig. 3). In the case of $65.9 \%$ of sampling points, analysis of tree-ring eccentricity yielded higher frequency of landslide events, compared to compression wood. The latter has yielded higher frequency of landslide events in the case of $18.2 \%$ of sampling points. In the case of $15.9 \%$ of sampling points, the same level of landslide activity has been yielded from both growth disturbances. In general, the map prepared based on tree-ring eccentricity shows a larger extent of high and medium level of landslide activity (>2.01 events/10 years and 1.01-2.00

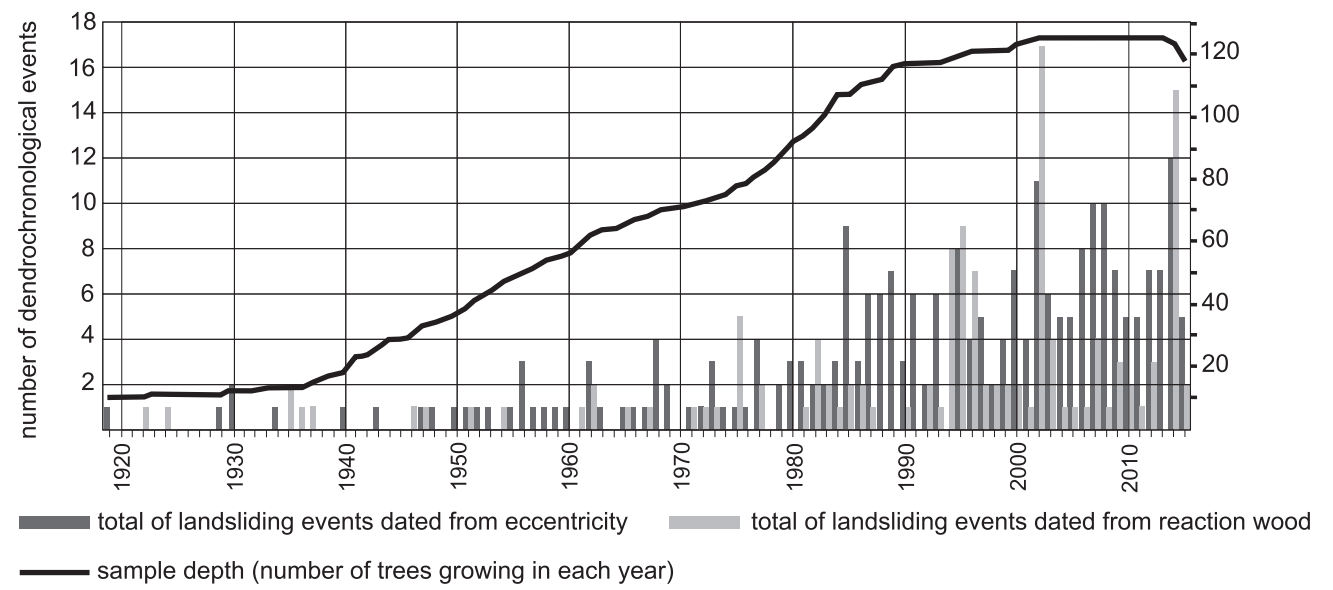

Fig. 2. Temporal occurrence of landslide events dated from tree-ring eccentricity and compression wood 
events/10 years) compared to the map developed based on compression wood (Fig. 3). However, the differences between the two maps are usually small and their scale can be observed in Figure 4. They do not exceed two events per 10 years on average if eccentricity outnumbers compression wood, and one event per 10 years on average if compression wood outnumbers eccentricity.

\section{DISCUSSION}

A combination of dendrogeomorphological analysis and GIS techniques has been applied to assess the frequency and landslide hazard. Landslide activity has been dated and mapped over the entire mountain massif based on reaction of trees: growth eccentricity and compression wood. The results fall in line with previous studies which show not only that eccentric growth and compression wood can occur together in one population of conifers or in one coniferous tree, but also that eccentric growth is usually more common (Timell, 1986; Wistuba et al., 2018). The reason lies probably in the higher sensitivity of tree-ring eccentricity that develops even after a slight tilting of the tree stem, while the development of compression wood requires larger angles of tilting. Šilhàn (2016) observed that the development of compression wood and eccentric tree rings depends mainly on the degree of stem tilting. Hejnowicz (2002) found that if stem tilting from a vertical position is less than $3.5^{\circ}$,

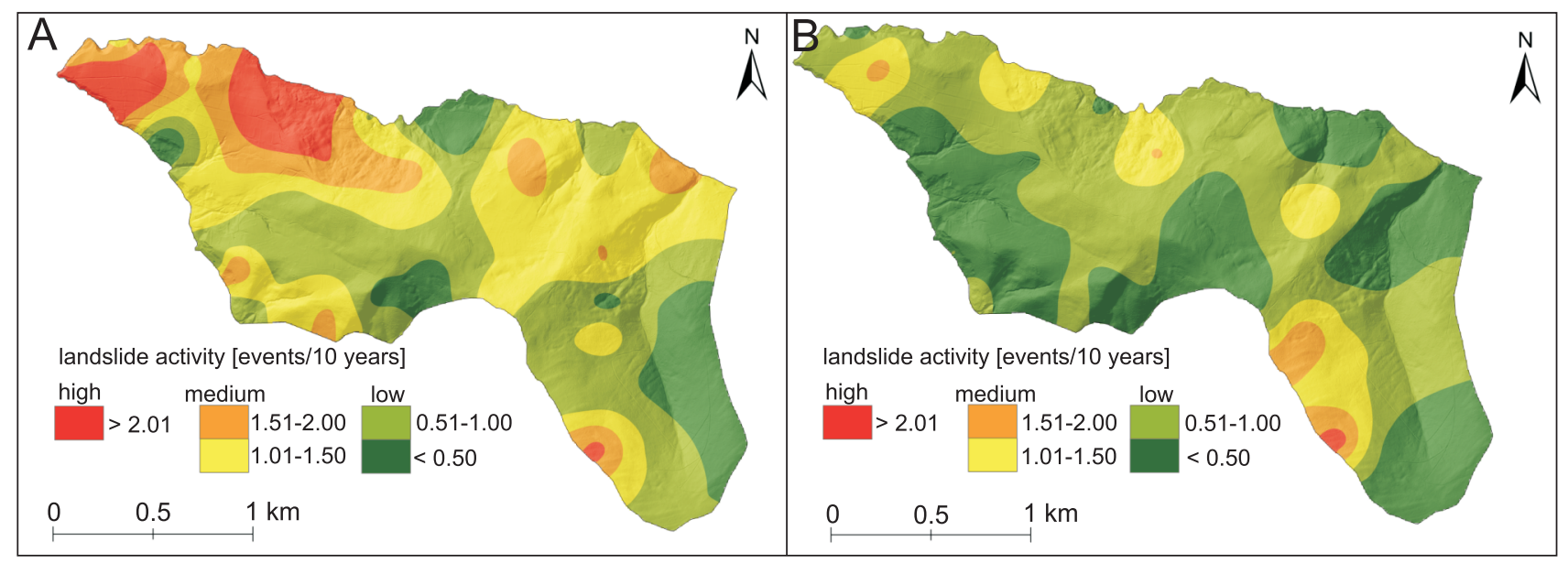

Fig. 3. Landslide activity maps developed from tree-ring eccentricity (A) and compression wood (B)

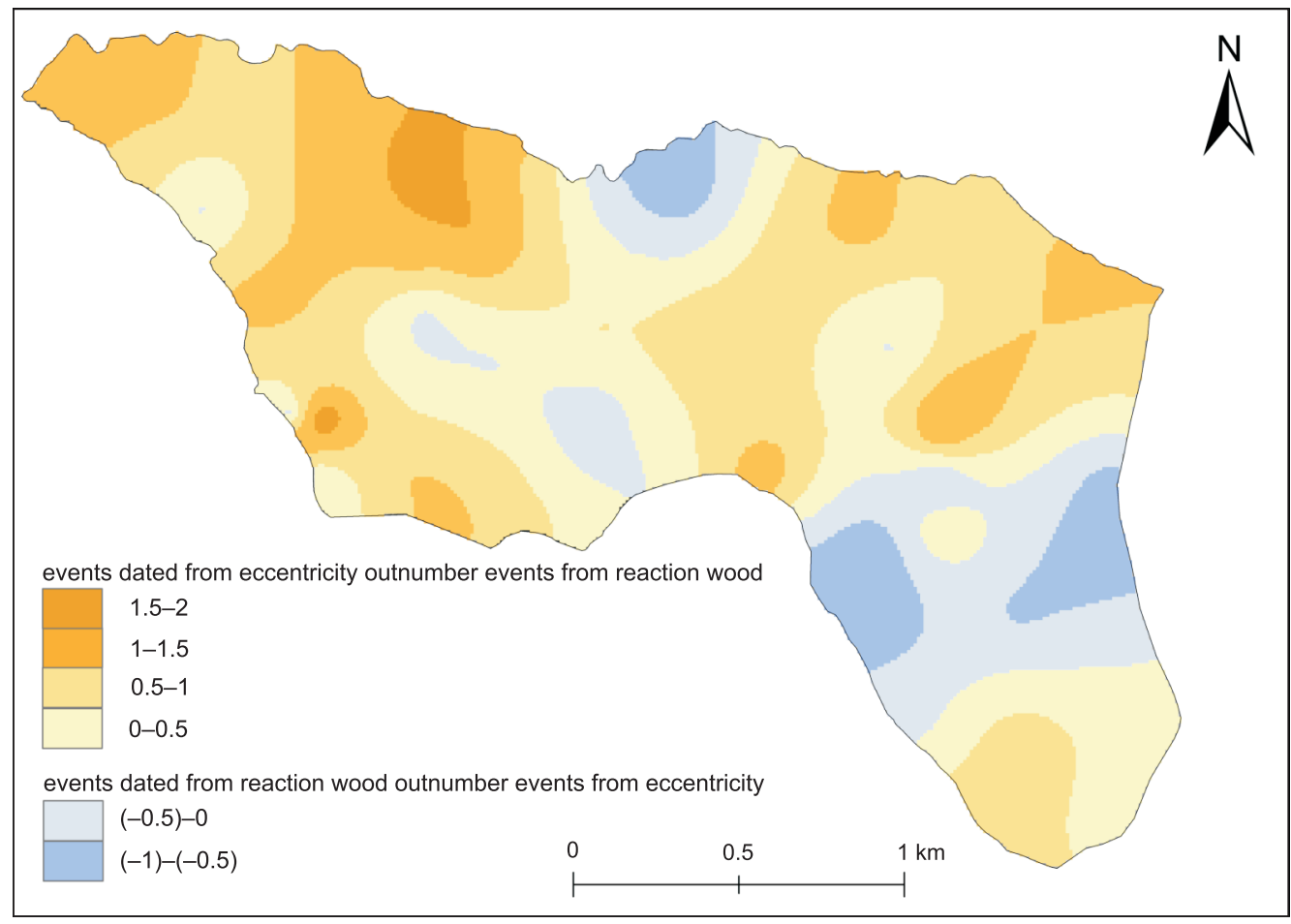

Fig. 4. Difference in the average number of events (average event frequency per 10 years) recorded by tree-ring eccentricity and by compression wood (calculated as raster of Figure $3 \mathrm{~A}$ minus raster of Figure $3 \mathrm{~B}$ ) 
only eccentric growth develops without any reaction wood. Pillow and Luxford (1937) found that the occurrence of compression wood in several hundred specimens of loblolly and longleaf pines (Pinus taeda and Pinus palustris) is related to stem tilting from a vertical position. The authors (Pillow and Luxford, 1937) have set a threshold of $3^{\circ}$ for stem deviation from a vertical position. On the other hand, Wiedenhoeft (2013) found that even a tree tilted by as little as $1-2^{\circ}$ can develop reaction wood. The threshold of the angle of stem tilting necessary to develop both eccentric growth and reaction wood depends on the species, physiological status and ontogenetic stage of a tree. Eccentric growth seems to be a more sensitive indicator of environmental processes (landsliding, wind, etc.) compared to reaction wood. Tree-ring eccentricity records the whole spectrum of events leading to stem tilting, while reaction wood records the strongest of them. This is confirmed by the results obtained in the study area where higher sensitivity of tree-ring eccentricity has been revealed (in $65.9 \%$ of sampling points, eccentricity yielded higher landslide activity). The combination of both growth disturbances, growth eccentricity and compression wood, can potentially be helpful in distinguishing landslide events of diverse intensity. However, there is a need for further studies comparing the occurrence of eccentric growth and reaction wood among trees of diverse species, age and degree of stem tilting.

The differences between the results of dating from tree-ring eccentricity and reaction wood can also originate from the methods applied to detect both growth disturbances. In our study, eccentric growth has been determined and analysed through a mathematical calculation of the percent index (Wistuba et al., 2013). A similar approach to eccentricity analysis has also been applied, e.g., by Casteller et al. (2007). At the same time, reaction wood is usually analysed visually (e.g., Bollschweiler et al., 2007; Migoń et al., 2010). Reaction wood is often divided into different classes:

- pronounced (severe) compression wood, which is considered as distinct and easy to recognize,

- mild (moderate) compression wood, which is not easy to detect as abnormal wood, but can be distinguished from normal wood under a microscope (Yumoto et al., 1983).

The visual determination of reaction wood may not be objective and depends on the researcher's methods and experience. Therefore, it is recommended to use microsections from core microtomes to determine the occurrence of reaction wood. This reduces the error in the identification of reaction wood (Gärtner and Nievergelt, 2010). Due to the differences in the level of stress (i.e. the angle of stem tilting) required for the eccentricity and reaction wood to develop, it is possible that the most reliable approach for landslide activity dating is to combine the results from both growth disturbances, as they may represent geomorphic events of diverse severity and velocity.

The dating of the onset sequences of eccentric growth and reaction wood allowed us to prepare landslide activity maps which may also be interpreted as landslide hazard maps since detailed knowledge on the spatial and temporal variability of landslide activity is crucial to determine landslide hazard (van Westen et al., 2008). A combination of landslide activity determined from tree rings and the airborne LiDAR data can provide particularly accurate results (Łuszczyńska et al., 2018). Such maps can be used in spatial management and planning. They can help to reveal areas with a higher hazard and risk of landslide occurrence, and areas which are safer for investments. Maps based on the results of dendrochronological dating provide information on actual landslide activity and its spatial variability. So far, landslide hazard maps were commonly based on landslide susceptibility, inferred from indirect factors that, in general, determine the occurrence of landslides, e.g. bedrock, slope inclination and land use (Lang et al., 1999). A further improvement and testing of the dendrochronological tools, based on eccentric growth and reaction wood, should allow a better assessment of the landslide hazard and risk in mountain areas.

\section{CONCLUSIONS}

The study allowed us to detect and date the recent landslide activity in the massif of Sucha Mountain (Western Carpathians, Central Europe). The spatial variability of landslide activity, dated from tree-ring eccentricity and compression wood of Norway spruce, has been demonstrated on two interpolated maps. The study shows relatively small differences between landslide activity maps yielded from tree-ring eccentricity and compression wood. The analysis of eccentric growth allowed detecting a greater number of events compared to reaction wood. This results from the fact that growth eccentricity develops even after a slight tilting of the tree stem, while reaction wood requires a larger degree of tilting. In addition, the methods applied for detecting eccentricity and compression wood differ significantly: eccentricity is usually dated through mathematical calculations, while compression wood is dated visually. Dating compression wood is less objective, because it partially depends on the individual methods and experience of the researcher. Nevertheless, eccentric growth is a more sensitive indicator of ground instability, allowing dating a wider spectrum of landslide events, while compression wood enables identifying the most severe events. Therefore, it seems justified to use both growth disturbances together in landslide dating.

The obtained results suggest that dating reaction wood and eccentric growth is useful in preparing landslide activity and hazard maps. The dendrochronological analysis of tree growth disturbances is a promising approach for determining landslide hazards in forested mountain areas and can be used in spatial management. Using dendrochronology provides a unique opportunity to asses landslide hazard based on reconstructions of landslide activity, reaching back over hundred years (depending on the age of the tree stand). Other methods commonly applied for landslide hazard assessment (e.g., aerial and satellite imagery, LiDAR and radar interferometry) provide much shorter datasets and therefore less accurate data on the general landslide hazard.

Acknowledgements. The study has been supported by the National Centre for Research and Development, Poland, within the scope of the project INNOTECHK3/IN3/58/228202/NCBR/15. The authors would like to thank Reviewers and Editor W. Granoszewski for their comments and suggestions, which helped to improve the manuscript. 


\section{REFERENCES}

Alcátara-Ayala, I., 2002. Geomorphology, natural hazards, vulnerability and prevention of natural disasters in developing countries. Geomorphology, 47: 107-124.

ArcGIS Help, 2017. Comparing interpolation methods. Available at: http://desktop.arcgis.com/en/arcmap/latest/tools/3d-analysttoolbox/comparing-interpolation-methods.htm

Bollschweiler, M., Stoffel, M., Ehmisch, M., Monbaron, M., 2007. Reconstructing spatio-temporal patterns of debris-flow activity with dendrogeomorphological methods. Geomorphology, 87: 337-351.

Casteller, A., Stökli, V., Villalba, R., Mayer, A.C., 2007. An evaluation of dendroecological indicators of snow avalanches in the Swiss Alps. Arctic, Antarctic, and Alpine Research, 39: 218-222.

García-Davalillo, J.C., Herrera, G., Notti, D., Strozzi, T., Álvarez Fernádez, I., 2014. DInSAR analysis of ALOS PALSAR images for the assessment of very slow landslides: the Tena Valley case study. Landslides, 11: 225-246.

Gätner, H., Nievergelt, D., 2010. The core-microtome: a new tool for surface preparation on cores and time series analysis of varying cell parameters. Dendrochronologia, 28: 85-92.

Glenn, N.F., Streutker, D.R., Chadwick, D.J., Thackray, G.D., Dorsch, S.J., 2006. Analysis of LiDAR-derived topographic information for characterizing and differentiating landslide morphology and activity. Geomorphology, 73: 131-148.

Hejnowicz, Z., 2002. Anatomia i histogeneza roślin naczyniowych (in Polish). PWN, Warszawa.

Hess, M., 1965. Vertical climatic vertical zones in the Polish Western Carpathians (in Polish with English summary). Zeszyty Naukowe UJ 115, Prace Geograficzne, 11: 1-265.

Highland, L.M., 2003. An Account of Preliminary Landslide Damage and Losses Resulting from the February 28, 2001, Nisqually, Washington, Earthquake. U.S. Geological Survey Reports. Open-File Report 2003, 11: 48.

Kjekstad, O., Highland, L., 2009. Economic and social impacts of landslides. In: Landslides Disaster Risk Reduction (eds. K. Sassa and P. Canuti): 573-587. Springer-Verlag, Berlin, Heidelberg, New York

Klose, M., Damm, B., Terhorst, B., 2014. Landslide cost modeling for transportation infrastructures: a methodological approach. Landslides, 12: 321-334.

Lang, A., Moya, J., Corominas, J., Schrott, L., Dikau, R., 1999 Classic and new dating methods for assessing the temporal occurrence of mass movements. Geomorphology, 30: 33-52.

Lopez-Saez, J., Corona, C., Stoffel, M., Schoeneich, P., Berger, F., 2012. Probability maps of landslide reactivation derived from tree-ring records: Pra Bellon landslide, southern French Alps. Geomorphology, 138: 189-202.

Łuszczyńska, K., Wistuba, M., Malik, I., Krąpiec, M., Szypuła, B., 2018. Dendrochronological dating as the basis for developing a landslide hazard map - an example from the Western Carpathians, Poland. Geochronometria, 45: 173-184.

Malik, I., Wistuba, M., 2012. Dendrochronological methods for reconstructing mass movements - an example of landslide activity analysis using tree-ring eccentricity. Geochronometria, 39: 180-196.

Malik, I., Wistuba, M., Migoń, P., Fajer, M., 2016. Activity of slow-moving landslides recorded in eccentric tree rings of Norway spruce trees (Picea abies Karst.) an example from the Kamienne Mts (Sudetes Mts, Central Europe). Geochronometria, 43: 24-37.

Metternicht, G., Hurni, L., Gogu, R., 2005. Remote sensing of landslides: an analysis of the potential contribution to geo-spa- tial systems for hazard assessment in mountainous environments. Remote Sensing of Environment, 98: 284-303.

Migoń, P., Pánek, T., Malik, I., Hradecký, J., Owczarek, P., Šilhán, K., 2010. Complex landslide terrain in the Kamienne Mountains, Middle Sudetes, SW Poland. Geomorphology, 124: 200-214.

Migoń, P., Kacprzak, A., Malik, I., Kasprzak, M., Owczarek, P., Wistuba, M., Pánek, T. 2014. Geomorphological, pedological and dendrochronological signatures of a relict landslide terrain, Mt Garbatka (Kamienne Mts), SW Poland. Geomorphology, 219: 213-231.

Petley, D.N., 2010. On the impact of climate change and population growth on the occurrence of fatal landslides in South, East and SE Asia. Quarterly Journal of Engineering Geology and Hydrogeology, 43: 487-496.

Pillow, M.Y., Luxford, R.F., 1937. Structure, occurrence and properties of compression wood. USDA Technical Bulletin, $\mathbf{5 4 6}$.

Prokop, A., Panholzer, H., 2009. Assessing the capability of terrestrial laser scanning for monitoring slow moving landslides. Natural Hazards and Earth System Sciences, 9: 1921-1928.

Schuster, R.L., Fleming, R.W., 1986. Economic Losses and Fatalities Due to Landslides. Environmental and Engineering Geoscience, 23: 11-28.

Schweingruber, F.H., 1996. Tree Rings and Environment. Dendroecology. Swiss Federal Institute for Forest, Snow and Landscape Research, WSL/FNP; Paul Haupt. Birmensdorf, Berne.

Seneta, W., Dolatowski, J., 2008. Dendrologia (in Polish). PWN, Warszawa.

Shroder, J.F., 1980. Dendrogeomorphology: review and new techniques of tree-ring dating. Progress in Physical Geography, 4: 161-188.

Stupnicka, E., 2013. Geologia regionalna Polski (in Polish). Uniwersytet Warszawski.

Šilhàn, K., 2016. How different are the results acquired from mathematical and subjective methods in dendrogeomorphology? Insights from landslide movements. Geomorphology, 253: 189-198.

Timell, T.E., 1986. Compression Wood in Gymnosperms. Springer-Verlag, Berlin, Heidelberg, New York.

van Westen, C.J., Castellanos Abella, E.A., Sekha, L.K., 2008. Spatial data for landslide susceptibility, hazards and vulnerability assessment: an overview. Engineering Geology, 102: 112-131.

Wiedenhoeft, A.C., 2013. Structure and function of wood. In: Handbook of wood Chemistry and Wood Composites. Second edition, Chapter 2 (ed. R.M. Rowell): 9-32. Taylor and Francis Group.

Wistuba, M., Malik, I., Gärtner, H., Kojs, P., Owczarek, P., 2013. Application of eccentric growth of trees as a tool for landslide analyses: the example of Picea abies Karst. in the Carpathian and Sudeten Mountains (Central Europe). Catena, 111: 41-55.

Wistuba, M., Malik, I., Krzemień, K., Gorczyca, E., Sobucki, M., Wrońska-Wałach, D., Gawior, D., 2018. Can low-magnitude earthquakes act as a triggering factor for landslide activity? Examples from the Western Carpathian Mts, Poland. Catena, 171: 359-375.

Yumoto, M., Ishida, S., Fukazawa, K., 1983. Studies on the formation and structure of the compression wood cells induced by artifactual initiation in young trees of Picea glauca. IV. Gradation of the severity of compression wood tracheids. Research Bulletins of the College Experiment Forests, 40: 409-454 